\title{
Control of protein synthesis during early cleavage of sheep embryos
}

\author{
I. M. Crosby, F. Gandolfi and R. M. Moor \\ AFRC Institute of Animal Physiology and Genetics Research, Department of Molecular \\ Embryology, Babraham, Cambridge CB2 4AT, U.K.
}

\begin{abstract}
Summary. Sheep embryos, radiolabelled with $\left[{ }^{35}\right.$ S]methionine, were studied during the first four cell cycles after fertilization to determine the stage at which the regulation of protein synthesis switches from the direction by maternal mRNA to mRNA transcribed by the embryonic genome. Total protein synthesis was consistently high during the first 2 cleavage divisions, dropped by $95 \%$ in the 3 rd cell cycle, remained low in the 4 th and increased again in the 5 th cycle. A consistent pattern of proteins was synthesized during the first 3 cell cycles after fertilization followed by major changes in subsequent cycles. The inhibition of transcription by $\alpha$-amanitin, an inhibitor of polymerase II, did not affect cleavage or protein synthesis during the first 3 cell cycles but blocked cleavage and protein synthesis thereafter. The results indicate that the full activation of transcription in sheep embryos occurs in the 4th cell cycle.
\end{abstract}

Keywords: embryo; proteins; $\alpha$-amanitin; transcription; sheep

\section{Introduction}

Early development in many species is dependent upon products which are synthesized by the oocyte during oogenesis and which remain inert until activated during maturation and cleavage (reviewed by Davidson, 1976). Although this maternal legacy includes a variety of different macromolecules, most interest has been aroused by the storage of messenger RNA which provides the major template for protein synthesis during the first few cleavage divisions. Careful studies have shown that transcription of new RNA from the embryonic genome occurs at very low levels from the first cycle (Davidson, 1976). This early transcription is not, however, required for the completion of the early cleavage divisions; sea urchin and amphibian embryos progress to the midblastula stage in the presence of transcriptional inhibitors. Similar detailed experiments have been carried out on mouse embryos to determine accurately the stage at which the transition from maternal to embryonic control of protein synthesis occurs (Braude et al., 1979; Bensaude et al., 1983; Bolton et al., 1984). The first transcription-dependent polypeptides are observed in mouse embryos $1.5 \mathrm{~h}$ after the first cleavage. The inhibition of transcription within the first hour after cleavage blocks the synthesis of these proteins and prevents further cleavage.

In this report we describe studies designed to identify the stage at which the transition from maternal direction of protein synthesis to embryonic regulation occurs in sheep embryos.

\section{Materials and Methods}

Superovulation and collection of embryos. Welsh Mountain ewes were injected with 900 i.u. PMSG (Folligon: Intervet Laboratories Ltd, Cambridge, U.K.) on Day 10-12 of the oestrous cycle, followed after $48 \mathrm{~h}$ by $125 \mu \mathrm{g}$ cloprostenol (Estrumate: ICI, Macclesfield, U.K.) and $24 \mathrm{~h}$ later by either $4 \mu \mathrm{g}$ gonadotrophin-releasing hormone analogue 
(Receptal: Hoechst, U.K. Ltd, Milton Keynes, U.K.) or 500 i.u. human chorionic gonadotrophin (Chorulon: Intervet Laboratories Ltd). The ewes were mated immediately after the final injection. Embryos were flushed from the oviducts $40-120 \mathrm{~h}$ after the final injection. Fertilization was assumed to take place $24 \mathrm{~h}$ after hCG/GnRH injection.

Radiolabelling and electrophoresis. Embryos were labelled for $4 \mathrm{~h}$ in $\left[{ }^{35} \mathrm{~S}\right]$ methionine (Amersham International plc, Amersham, U.K.; sp.act. $>1000 \mathrm{Ci} / \mathrm{mmol}$ ) at a radioactive concentration of $500 \mu \mathrm{Ci} / \mathrm{ml}$ in Dulbecco's phosphatebuffered saline supplemented with bovine serum albumin $(4 \mathrm{mg} / \mathrm{ml})$ and sodium pyruvate $(40 \mu \mathrm{g} / \mathrm{ml})$. The incorporation of radiolabel into protein was measured by TCA precipitation (total protein synthesis) while the profile of proteins was identified on 8-15\% linear gradient SDS-polyacrylamide gels, as described in detail by Osborn et al. (1981).

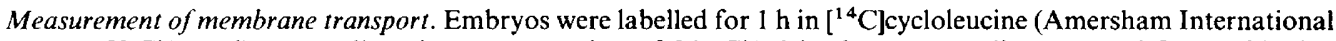
plc; sp.act. $59 \mathrm{Ci} / \mathrm{mmol}$ ) at a radioactive concentration of $24 \mu \mathrm{Ci} / \mathrm{ml}$ in the same medium as used for methionine labelling and uptake of label was measured as described by Moor \& Smith (1979).

Embryo culture. Embryos were cultured in TCM 199 with Earle's salts (Gibco Europe Ltd, Paisley, U.K.) + 10\% fetal calf serum on monolayers of sheep oviduct cells as described by Gandolfi \& Moor (1987). Some of the embryos were cultured in the presence of $\alpha$-amanitin $(10 \mu \mathrm{g} / \mathrm{ml}$, Sigma, U.K., Poole, U.K.). To buffer the adverse effect of $\alpha$-amanitin on division and secretion of the cells the embryos were placed on fresh cells every $24 \mathrm{~h}$. The same treatment was given also to the control embryos.

After culture, embryos were fixed and stained with lacmoid and the numbers of cell nuclei were recorded.

\section{Results}

Cleavage rates of sheep embryos in vivo

The results of our studies, together with those of Moore (1959) and Lawson (1970), indicate that the duration of the first mitotic cycle in sheep embryos is approximately $24 \mathrm{~h}$. The $2 \mathrm{nd}$, 3rd and 4 th cycles are short (about $12 \mathrm{~h}$ each) while the 5 th cycle reverts to about $24 \mathrm{~h}$ in length. Thus by $48 \mathrm{~h}$ after hCG/GnRH $32 \%$ of eggs were recovered at the 2-cell stage and by $61-63 \mathrm{~h} 30 \%$ were at 8 -cell stage. Division to 16-cells occurred by $87-92 \mathrm{~h}$ and early blastocysts were recovered by $119-120 \mathrm{~h}$ (Table 1$)$.

Table 1. Developmental stages of sheep embryos recovered after superovulation

\begin{tabular}{cccrrrrrr}
\hline $\begin{array}{c}\text { Time after } \\
\text { hCG/GnRH } \\
\text { (h) }\end{array}$ & $\begin{array}{c}\text { Time after } \\
\text { ovulation } \\
\text { (h) }\end{array}$ & $\begin{array}{c}\text { Total no. } \\
\text { of embryos }\end{array}$ & 1 & 2 & 4 & 8 & $16+$ & Blastocyst \\
\hline Up to 45 & Up to 21 & 95 & 95 & 0 & 0 & 0 & 0 & 0 \\
$46-48$ & $22-24$ & 116 & 79 & 37 & 0 & 0 & 0 & 0 \\
$61-63$ & $37-39$ & 71 & 0 & 0 & 50 & 21 & 0 & 0 \\
$69-72$ & $45-48$ & 99 & 0 & 0 & 2 & 97 & 0 & 0 \\
$87-88$ & $63-64$ & 27 & 0 & 0 & 0 & 12 & 15 & 0 \\
100 & 76 & 8 & 0 & 0 & 0 & 0 & 8 & 0 \\
112 & 88 & 5 & 0 & 0 & 0 & 0 & 5 & 0 \\
$119-120$ & $95-96$ & 22 & 0 & 0 & 0 & 0 & 17 & 5 \\
\hline
\end{tabular}

\section{Requirements for transcription during early cleavage}

Table 2 shows firstly the rate of cleavage of embryos recovered from sheep during the first 3 cell cycles and maintained thereafter in culture in plain medium for a period equivalent to $120 \mathrm{~h}$ after hCG/GnRH. Virtually all the embryos cleaved regularly to the 8-cell stage and about $50 \%$ progressed beyond the 16-cell stage. Embryos recovered at the 1-to 4-cell stage and cultured thereafter with the transcription inhibitor $\alpha$-amanitin cleaved regularly to the 8-cell stage but none developed to the 16-cell stage. Embryos which had already cleaved to the 8-cell stage in vivo underwent one further cleavage to 16-cells in the presence of $\alpha$-amanitin whereas equivalent embryos cultured in plain medium cleaved to 32-cells or beyond. The combined results suggest that cleavage to the 8-cell 
Table 2. The effect of $\alpha$-amanitin on the cleavage of sheep embryos in vitro

\begin{tabular}{|c|c|c|c|c|c|c|c|c|}
\hline \multirow{2}{*}{$\begin{array}{l}\text { Cell stage } \\
\text { at start } \\
\text { of culture }\end{array}$} & \multirow{2}{*}{$\begin{array}{l}\text { No. of days } \\
\text { in culture }\end{array}$} & \multirow{2}{*}{$\begin{array}{l}\text { Presence of } \\
\alpha \text {-amanitin }\end{array}$} & \multirow{2}{*}{$\begin{array}{l}\text { Total no. } \\
\text { of embryos }\end{array}$} & \multicolumn{5}{|c|}{ Cell stage at end of culture } \\
\hline & & & & $1-4$ & $5-8$ & $9-12$ & $13-16$ & $17+$ \\
\hline 1 & 4 & $\bar{t}$ & $\begin{array}{l}22 \\
22\end{array}$ & $\begin{array}{l}0 \\
3\end{array}$ & $\begin{array}{r}2 \\
18\end{array}$ & $\begin{array}{l}5 \\
1\end{array}$ & $\begin{array}{l}5 \\
0\end{array}$ & $\begin{array}{r}10 \\
0\end{array}$ \\
\hline 2 & 3 & - & $\begin{array}{r}10 \\
9\end{array}$ & $\begin{array}{l}0 \\
0\end{array}$ & $\begin{array}{l}0 \\
7\end{array}$ & $\begin{array}{l}1 \\
2\end{array}$ & $\begin{array}{l}3 \\
0\end{array}$ & $\begin{array}{l}6 \\
0\end{array}$ \\
\hline 4 & 3 & $\overline{+}$ & $\begin{array}{r}9 \\
17\end{array}$ & $\begin{array}{l}0 \\
0\end{array}$ & $\begin{array}{r}0 \\
16\end{array}$ & $\begin{array}{l}0 \\
1\end{array}$ & $\begin{array}{l}0 \\
0\end{array}$ & $\begin{array}{l}9 \\
0\end{array}$ \\
\hline 8 & 2 & $\overline{-}$ & $\begin{array}{l}17 \\
23\end{array}$ & - & $\begin{array}{l}0 \\
1\end{array}$ & $\begin{array}{l}1 \\
7\end{array}$ & $\begin{array}{r}3 \\
15\end{array}$ & $\begin{array}{r}13 \\
0\end{array}$ \\
\hline
\end{tabular}

Table 3. Incorporation of $\left[{ }^{35}\right.$ S $]$ methionine into

TCA-precipitable material by sheep embryos

\begin{tabular}{ccc}
\hline & Time after \\
Stage & hCG/GnRH (h) & c.p.m./embryo/h \\
\hline 1 & Up to 48 & $13463 \pm 778(96)$ \\
2 & $46-48$ & $11487 \pm 1012(29)$ \\
4 & $61-63$ & $11727 \pm 1302(25)$ \\
8 & $61-88$ & $472^{*}(78)$ \\
$>$ 16 morula & $87-112$ & $643^{*}(43)$ \\
Blastocyst & 120 & $3225 \pm 463(5)$ \\
\hline
\end{tabular}

Values are mean \pm s.e.m. for the no. of embryos in parentheses.

*Embryos combined for analysis.

stage is not dependent upon new transcription. Cleavage to 16-cells and beyond is, by contrast, totally dependent on newly synthesized mRNA by the embryonic genome.

Changes in total protein synthesis during early cleavage

Total TCA-precipitable protein synthesis measured by the incorporation of $\left[{ }^{35}\right.$ S]methionine during 4-h labelling periods immediately after embryo recovery in each of the first 5 cell cycles is shown in Table 3. There was no significant change in the level of incorporation up to the 4-cell stage but after cleavage to 8-cells levels of incorporation dropped precipitously to less than $5 \%$ of the previous level. This low level of incorporation persisted throughout the morula stage and the earliest evidence of an increasing rate of synthesis was observed in early blastocysts at $120 \mathrm{~h}$ after hCG/GnRH.

The pattern of incorporation observed during cleavage was found to occur in the same form in unfertilized eggs. Unfertilized eggs recovered from the oviducts of donor sheep at $45-48 \mathrm{~h}$ and 61-63 h after hCG/GnRH incorporated $15386 \pm 1444$ and $11445 \pm 1093$ c.p.m. $\left[{ }^{35}\right.$ S]methionine respectively, values which were not significantly different from those incorporated by fertilized eggs at the same stage relative to $\mathrm{hCG} / \mathrm{GnRH}$ administration. Unfertilized eggs recovered at $69-72 \mathrm{~h}$ after hCG/GnRH, incorporated only $15 \%$ (1766 \pm 572 c.p.m.) as much as did unfertilized eggs 
recovered $8 \mathrm{~h}$ earlier. This time of decline in incorporation rate in unfertilized eggs coincided exactly with the decline after fertilization as embryos entered the 8-cell stage.

Membrane uptake studies using a non-metabolizable amino acid, cycloleucine, were carried out to discover whether the precipitous drop in methionine incorporation to the $3 \mathrm{rd}$ cell cycle could be accounted for by a decrease in amino acid transport. Embryos recovered from donors at the 8-cell stage accumulated cycloleucine at a rate of $2.33 \pm 0.13 \mathrm{pmol} / \mathrm{embryo} / \mathrm{h}(n=12)$ while the rate of entry in control oocytes at metaphase II was $5.66 \pm 0.49 \mathrm{pmol} /$ oocyte/h $(n=8)$. Since cycloleucine is transported on the same carrier system as methionine it is clear that a decline in membrane uptake occurs during cleavage. However, the decline in uptake is considerably smaller than the precipitous drop in total incorporation.

\section{Changes in protein synthesis during cleavage}

A remarkably similar pattern of proteins was synthesized by newly fertilized, 2-cell and 4-cell embryos (Fig. 1). In contrast, the pattern of proteins synthesized by early blastocysts differs markedly from that of the earlier cleavage-staged embryos. The major differences between $1-$ to 4-cell embryos on the one hand and blastocysts on the other are indicated on the figure by letters A-D (Fig. 2).

The low levels of methionine incorporation in embryos between the 8-cell stage and blastocyst formation made it difficult to study the pattern of protein synthesis in these late cleavage stages. By combining embryos at similar cleavage stages it was, however, possible to distinguish proteins in 16- and 32-cell embryos which differed from those of the earlier cleavage stages and resembled instead those synthesized by blastocysts. For example, two proteins marked C and D were characteristic of blastocysts but were also prominent in 16-cell embryos.

\section{Discussion}

These experiments indicate that for the first 3 cell cycles the sheep embryo synthesizes proteins at a high level and with no major changes in the pattern of synthesis. The inhibition of transcription during this period neither blocks cleavage nor inhibits protein synthesis. The first major changes in protein synthesis at the 16-cell stage are preceded both by a precipitous decline in amino acid incorporation and by the onset of $\alpha$-amanitin sensitivity.

These results contrast markedly with those obtained in studies of the mouse embryo, which becomes dependent on transcription immediately after the first cleavage with major changes in the proteins synthesized by the late 2-cell stage (Bolton et al., 1984). In a similar study Norris et al. (1985) have shown major transcription-dependent changes in the 2-cell embryo of Mongolian gerbils. Studies of rabbit embryos have produced inconsistent results, suggesting a dependence on transcription at the 4-cell or the 8-cell stage (Manes, 1973). We have re-examined the effects of $\alpha$-amanitin on rabbit embryos and have consistently found a block to cleavage at the 8-cell stage which coincides with major changes in protein synthesis (I. M. Crosby \& R. M. Moor, unpublished observations). It therefore appears that rodent embryos become dependent on transcription at an earlier stage than that of the other mammalian species so far studied. This is, perhaps, to be expected since blastocyst formation also occurs 1-2-cell divisions earlier in mice and gerbils than in rabbits or sheep.

Our results further suggest that transcription occurring in the sheep embryo before the 8-cell stage is not essential for early cleavage. From this one would postulate that a 4- or 8-cell nucleus may be able to substitute for the nucleus of a 1-cell egg. That this is true has been demonstrated by the successful development of embryos produced by injection of 8-cell nuclei into enucleated eggs (Willadsen, 1986). In contrast, the nucleus of the 4- and 8-cell mouse embryo, which has already begun major transcription, cannot support the development of enucleated eggs (McGrath \& Solter, 

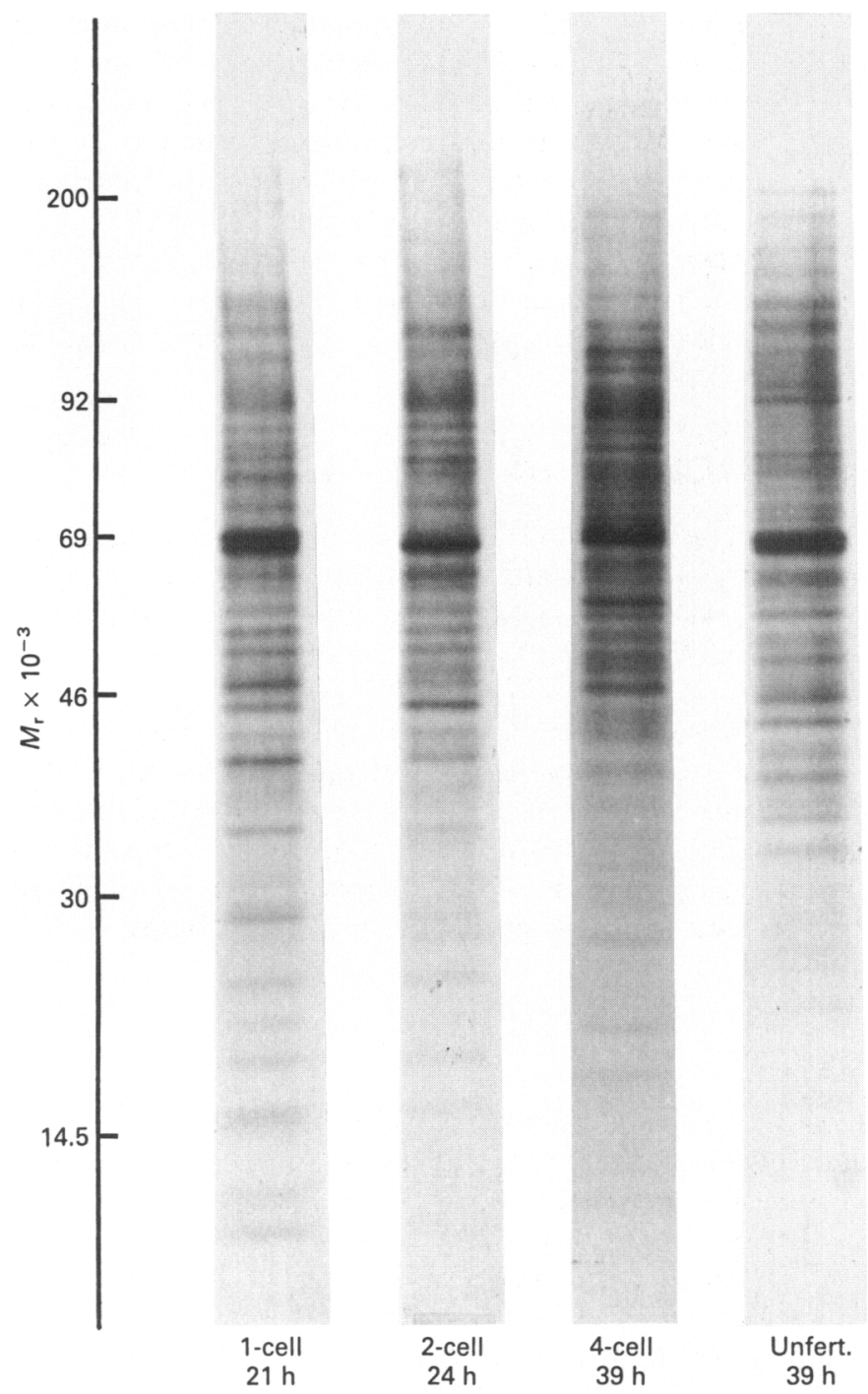

Fig. 1. Fluorograms of SDS-PAGE gels of proteins synthesized by 1-, 2- and 4-cell sheep embryos and by unfertilized eggs recovered $39 \mathrm{~h}$ after ovulation. Each track is derived from a single embryo.

1984; Howlett et al., 1988). This supports the hypothesis that a transcriptionally active nucleus cannot successfully interact with a cytoplasm which is still operating on an inherited maternal programme.

Our previous studies of the maturation of the sheep oocyte have shown that dependence on transcription ceases within $2 \mathrm{~h}$ of the triggering of maturation (Osborn \& Moor, 1983), i.e. about $24 \mathrm{~h}$ before fertilization. Together with the data obtained in the present study, this implies a total period of dependence on stored message of approximately $65 \mathrm{~h}$. This is considerably longer than in the mouse $(\sim 36 \mathrm{~h})$ or in Xenopus, which although progressing to 10000 cells does so in less than $24 \mathrm{~h}$ after fertilization.

The most unexpected finding in the present study was the $95 \%$ drop in the level of incorporation of labelled methionine by sheep embryos at the time of the 3rd cleavage. The possibility that this 

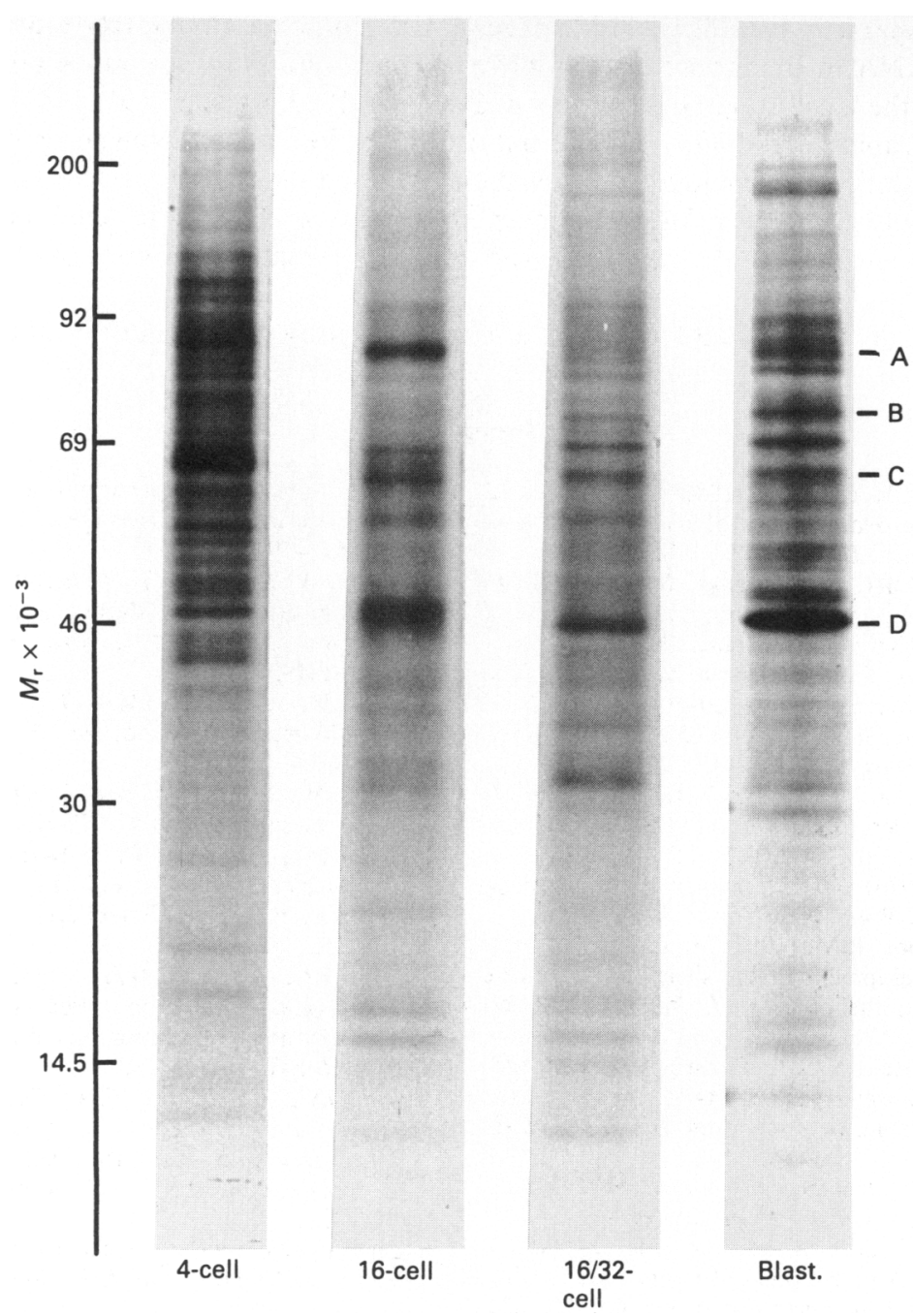

Fig. 2. Fluorograms of SDS-PAGE gels of proteins synthesized by sheep embryos from the 4-cell to the early blastocyst stage. The 16-cell and 32-cell tracks consist of 8 embryos combined to give one sample. Bands A-D are the major differences between 1-4-cell embryos and blastocysts.

might be due to a shutdown of membrane transport was investigated and although there is a decrease this is not enough to account for the drop in incorporation. Significant decreases in incorporation at the time of onset of transcription have also been found for the pig embryo ( $\mathrm{J}$. C. Osborn \& C. Polge, unpublished observations), the gerbil embryo (Norris et al., 1985) and the mouse embryo (Love, 1982), but do not apparently occur in the rabbit embryo (I. M. Crosby \& R. M. Moor, unpublished observations). There are two possible explanations for the dramatic drop in methionine incorporation in sheep embryos; (i) there is a major decrease in the rate of protein synthesis at this stage, and (ii) the label is diluted by an increase in the amount of unlabelled methionine in the embryonic pool, possibly due to a breakdown of protein. Pulse-chase experiments conducted by us do not support the idea of a major breakdown of protein at the 8-cell stage. We favour the first explanation which suggests a sudden cessation of translation which could be 
caused or accompanied by the degradation or sequestration of maternal mRNA. Studies of the fate of maternal mRNA in the mouse embryo have shown a rapid disappearance after the onset of transcription at the 2-cell stage (Bachvarova \& De Leon, 1980; Bolton et al., 1984). It seems likely that an equally rapid degradation of maternal mRNA occurs in the 8-cell sheep embryo and the subsequent translation of remaining and new message is at a much lower level than previously. We are currently studying the translation by sheep embryos of exogenous injected message to throw light upon the mechanism of the transition from maternal to embryonic control of development.

We thank A. Stephen Gaunt for helpful discussions during the preparation of this paper.

\section{References}

Bachvarova, R. \& De Leon, V. (1980) Polyadenylated RNA of mouse ova and loss of maternal RNA in early development. Devl Biol. 74, 1-8.

Bensaude, O., Babinet, C., Morange, M. \& Jacob, F. (1983) Heat shock proteins, first major products of zygotic gene activity. Nature, Lond. 305, 331-333.

Bolton, V.N., Oades, P.J. \& Johnson, M.H. (1984) The relationship between cleavage, DNA replication and gene expression in the mouse 2-cell embryo. $J$. Embryol. exp. Morph. 79, 139-163.

Braude, P.R., Pelham, H.R.B., Flach, G. \& Lobbato, R. (1979) Post transcriptional control in the early mouse embryo. Nature, Lond. 282, 102-105.

Davidson, E.H. (1976) Gene Activity in Early Development. Academic Press, New York.

Gandolfi, F. \& Moor, R.M. (1987) Stimulation of early embryonic development in the sheep by co-culture with oviduct epithelial cells. J. Reprod. Fert. 81, 23-28.

Howlett, S.K., Barton, S.C. \& Surani, M.A.H. (1988) Nuclear cytoplasmic interactions following nuclear transplantation in mouse embryos. Development, (in press).

Lawson, R.A.S. (1970) Embryonic survival in the ewe and cow. Ph.D. thesis, University of Cambridge.

Love, N.K. (1982) Post fertilization activation of stored maternal mRNA in the one-cell mouse egg. In Proteins and Steroids in Early Pregnancy, pp. 219-231. Eds H. M. Beier \& P. Karlson. Springer-Verlag, Berlin.
Manes, C. (1973) The participation of the embryonic genome during early cleavage in the rabbit. Devl Biol. 32, 453-459.

McGrath, J. \& Solter, D. (1984) Inability of mouse blastomere nuclei transferred to nucleated zygotes to support development in vitro. Science, N.Y. 226, 1317-1319.

Moor, R.M. \& Smith, M.W. (1979) Amino acid transport in mammalian oocytes. Expl Cell. Res. 119, 333-341.

Moore, N.W. (1959) Studies on the reproduction of sheep. Ph.D. thesis, University of Cambridge.

Norris, M.L., Barton, S.C. \& Surani, M.A.H. (1985) Changes in protein synthesis during early cleavage of the Mongolian gerbil embryo. J. exp. Zool. 236, 149-153.

Osborn, J.C. \& Moor, R.M. (1983) Time-dependent effects on $\alpha$-amanitin on nuclear maturation and protein synthesis in mammalian oocytes. J. Embryol. exp. Morph. 73, 317-338.

Osborn, J.C., Moor, R.M., Cran, D.G. \& Walters, D.E. (1981) Selective effect of gonadotrophins in cell coupling, nuclear maturation and protein synthesis in mammalian oocytes. J. Embryol. exp. Morph. 61, $347-365$.

Willadsen, S.M. (1986) Nuclear transplantation in sheep embryos. Nature, Lond. 320, 63-65.

Received 12 August 1987 